\title{
Effect of Wastewater Fertigation on Growth Performance, Yield and Quality Parameters of Solanum melongena L. (Local Long)
}

\author{
Farooq A. Lone ${ }^{1 *}$ and Nayar A. Kirmani ${ }^{2}$ \\ ${ }^{1}$ Division of Environmental Sciences, ${ }^{2}$ Division of Soil Sciences, S.K. University of \\ Agricultural Sciences and Technology of Kashmir, Shalimar, Srinagar-191 121 J\&K (India) \\ *Corresponding author
}

\section{A B S T R A C T}

\section{Keywords}

Wastewater, Brinjal, Growth performance, Agriculture, Fertigation

\section{Article Info}

Accepted:

20 February 2018

Available Online:

10 March 2018
Wastewater can be utilized in a variety of ways like irrigation of agricultural land, landscape, aquaculture, urban, industrial, recreational use and also for groundwater recharge. The major objective of wastewater use in agriculture is to optimize its benefits in terms of fertigation i.e., irrigation and nutrient supply with which it is loaded. In the present study, an experiment was carried out to assess the growth performance of Solanum melongena L. (Local Long) under irrigation with different concentrations of domestic wastewater (grey and black water) in combination with recommended dose of fertilizers (RDF). This field experiment was carried out for two consecutive years 2012-2013 and involved 6 treatments (T1-T6) with three replications in RCBD. Before being utilized, wastewater was stabilized for 20-25 days in open containers. The study shows that the concentrations of the various physico-chemical parameters (viz., pH, EC, OC, N, P, K, Ca, $\mathrm{Mg}, \mathrm{Cu}, \mathrm{Fe}, \mathrm{Mn}, \mathrm{Zn}, \mathrm{Cd}, \mathrm{Ni}, \mathrm{Cr}, \mathrm{Pb}$ ) of waste water and pre and post experiment soil samples are within permissible limits. The highest yield of brinjal $\left(330.04 \mathrm{q} \mathrm{ha}^{-1}\right)$ was recorded in T1 (Recommended dose of fertilizers =RDF) followed by $299.59 \mathrm{q} \mathrm{ha}^{-1}$ (T5=50\% black water and 50\% RDF ), $287.69 \mathrm{q} \mathrm{ha}^{-1}$ (T4: 50\% grey water and 50\%RDF), $280.62 \mathrm{q} \mathrm{ha}^{-1}$ (T6: 50\% black water and 50\% grey water), $273.48 \mathrm{q} \mathrm{ha}^{-1}\left(\mathrm{~T}_{2}: 100 \%\right.$ grey water) and least of $266.33 \mathrm{q} \mathrm{ha}^{-1}$ in T3 (100\% black water). Quality parameters viz., TSS, ascorbic acid, Chl-a, Chl-b, total-chl, carbohydrates and protein content between various treatments exhibited different trends. This study urges upon the averment that irrigation with stabilized grey and black water does not have any adverse effects on the soil chemistry and thus there is an option for recycling of wastewater in agriculture

\section{Introduction}

With ever increasing population and shrinkage of land resources, demand for food and freshwater is a growing concern. Wastewater is generated in bulk quantity from both domestic as well as industrial estates and its crude disposal into the environment is posing a tremendous threat to environment. In developing countries including India, wastewater is commonly a choice for irrigating agricultural field (Nath et al., 2009). Globally, approximately 20\% of manufactured nitrogen and phosphorous is 
contained in domestic wastewater (Batstone et al., 2015) and it has been considered as low price fertilizer because of its high $\mathrm{N}, \mathrm{P}$ and $\mathrm{K}$ content (Chaw and Reves, 2001) although domestic wastewater by itself cannot completely fulfill fertilizer requirements but combinations of wastewater with other nutrient sources can work wonders. Waste water is rich in organic matter and also contains appreciable amounts of macro and micro-nutrients (Gupta et al., 1995). Accordingly nutrients levels of soil are expected to improve considerably using continuous irrigation with waste water (Ramirez-Fuentes et al., 2002; Rattan, et al., 2005). Thus, recycling of wastewater shall pave avenues in agricultural industry in terms of minimizing the use of inorganic fertilizers whose long-term utilization pose negative pressures on natural environment. The main objective of this experiment was to estimate the growth performance, quality parameters and yield responses of Brinjal (Solanum melongena L. Local Long) under irrigation with different doses of untreated domestic wastewater (grey and black water). Moreover, effect of wastewater fertigation on the physicochemical parameters of soil and plant tissues was studied to investigate the prospects of safe use of urban wastewater for irrigation.

\section{Materials and Methods}

\section{Study area}

The experiment was conducted during summer (Kharif) 2012 and 2013 in the experimental field at FoA Wadura, SKUAST-

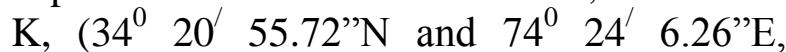
Altitude of $1580 \mathrm{~m}$ a.s.1), Kashmir. The area is characterized by temperate climatic conditions with mean maximum and minimum temperature during the growing season as $26.08^{0} \mathrm{C}$ and $11.78^{0} \mathrm{C}$ respectively.

\section{Experimental design and the crop}

The field was prepared for assessing the impact of different concentrations of wastewater and recommended doses of fertilizers on growth, yield and quality of Solanum melongena L. Local Long, one of the prime grown summer vegetables of Kashmir Valley. The experiment was laid in completely randomized block design and involved six treatments (T1: Recommended dose of fertilizers; T2: 100\% Grey water; T3: 100\% Black water; T4: 50\% Grey water + 50\% RDF; T5: 50\% black water + 50\% RDF; T6: $50 \%$ black water $+50 \%$ Grey water) each with three replication and an untreated control (C) irrigated with fresh water. The fertilizers $\mathrm{N}, \mathrm{P}$ and $\mathrm{K}$ were applied to the crop at the rates of 120,90 and $60\left(\mathrm{~kg} \mathrm{ha}^{-1}\right)$, as urea, DAP and MOP respectively. The plot dimension for the experiment was $2.4 \times 1.8 \mathrm{~m}$ with $45 \mathrm{~cm}$ spacing between the plants and 60 $\mathrm{cm}$ between the rows. The grey water and black water for irrigation was obtained from the hostels and households located in the vicinity of the university campus and stabilized in open tanks for 20-25 days before being put to use.

\section{Water analysis}

Samples of grey water, black water and fresh water were subjected to chemical analysis during both the years of experimentation. Physicochemical parameters viz., $\mathrm{pH}$ and EC (Piper, 1966), N, P, K, alkalinity, Ca, Mg, Zn, $\mathrm{Cu}, \mathrm{Mn}, \mathrm{Fe}, \mathrm{Cd}$ and $\mathrm{Ni}$ were determined following APHA, 2005.

\section{Soil analysis}

Composite soil samples were collected from each plot at the depth of $0-30 \mathrm{~cm}$ before transplantation and after harvest. Samples were oven dried, ground, sieved and analysed for $\mathrm{pH}$, EC (Piper, 1966), total $\mathrm{N}$ by Kjeldahl 
method (Jackson, 1973), available P (Olsen, 1954), organic carbon (Walkely and Black, 1934) and exchangeable $\mathrm{Ca}, \mathrm{Mg}$ and $\mathrm{K}$ using the ammonium acetate method (Hesse, 1971). Further $\mathrm{Zn}, \mathrm{Mn}, \mathrm{Cu}, \mathrm{Fe}, \mathrm{Ni}$ and $\mathrm{Cd}$ were analysed by using atomic absorption spectrophotometer.

\section{Crop yield and plant tissue analysis}

Fruit samples were harvested from each plot, dried in a hot air oven at $70^{\circ} \mathrm{C}$ for 48 hours, powdered in a grinder and subjected to chemical analysis for the estimation of carbohydrate (Dobois et al., 1956), protein (Lowry et al, 1951) and ascorbic acid contents (Sadasivam and Balasubramanian, 1987). Fruit samples were also analyzed for TSS by using Refractometer. Photosynthetic pigments in the foliage were also estimated (Hiscox and Isrealstam, 1979). Mineral contents of plant tissues were determined by the method of wet oxidation using a mixture of $\mathrm{HNO}_{3}$ and $\mathrm{HClO}_{4}(\mathrm{AOAC}, 1984)$. Total $\mathrm{N}$ was determined by the Kjeldahl method (Jackson, 1973), P by blue phosphomolybdic complex by a spectrophotometer, $\mathrm{K}$ by flame photometer and $\mathrm{Ca}, \mathrm{Mg}, \mathrm{Zn}, \mathrm{Fe}, \mathrm{Mn}, \mathrm{Cu}, \mathrm{Cd}$ and $\mathrm{Ni}$ by atomic absorption spectrophotometer Total weight of fruits (kg/plot) at each picking was added to obtain the total fruit yield per plot and expressed as quintals per hectare $\left(\mathrm{q} \mathrm{ha}{ }^{-1}\right)$. Pooled data of the two years recorded during the experiment was subjected to ANOVA, followed by least significant difference $(C D, p \leq 0.05)$ using $R$ software statistical package (Gomez and Gomez, 1984).

\section{Results and Discussion}

\section{Water chemistry}

Data regarding the physicochemical characteristics of black, grey and fresh water are presented in Table 1. The values were in lower levels than those permitted for upper threshold set of irrigation water and safe reuse in agriculture. According to PCB (2003), pH of wastewater should range between 6.5 and 8.5 and EC should not exceed $2.25 \mathrm{dS} / \mathrm{m}$. Our study show that both these parameters of wastewater were within range. Alkalinity, phosphate, $\mathrm{Na}, \mathrm{Ca}, \mathrm{Mg}, \mathrm{Zn}, \mathrm{Cu}, \mathrm{Fe}, \mathrm{Mn}$ and $\mathrm{Cd}$ were found higher in grey water compared to black and fresh water while as chloride, flouride, sulphate, ammonium and potassium were found in higher concentration in black water. The concentration of $\mathrm{Ni}$ and $\mathrm{Pb}$ did not show any significant variation. However all the parameters were within permissible limits.

\section{Physico-chemical characterization of the soil}

The texture of soil was loamy and wastewater treatments did not pose any considerable effect on the soil $\mathrm{pH}$ value as also reported by Shahalam et al. (1998) (Table 2). The soil pH of various treatments ranged from 6.24 to 7.53 while EC ranged from 0.20 to 1.05 . Significant increase in EC was detected in soil after the experiment (Vela et al 2007, Lone et al., 2013), which might be due to the relatively higher EC of waste water and formation of metallic salts-complexes of organic matter and heavy metals (Ahmed et al., 2010). Though $\mathrm{N}$ and $\mathrm{P}$ contents did not exhibit any significant change, the composition of $\mathrm{K}$ show increased trends in the treatments T6 (under irrigation with 50\% black and $50 \%$ grey water) which may be due to the fact that that the availability of major macronutrients in wastewater was high and enhanced their concentration in soil. Similarly, the contents of micronutrients (Fe, $\mathrm{Mn}$ ) were found higher in the treatments (T6) while as $\mathrm{Zn}$ and $\mathrm{Cu}$ were higher in the treatments (T3) under irrigation with $100 \%$ black water. The $\mathrm{Ca}$ was higher in treatments (T4) with $50 \%$ grey water and $50 \%$ RDF while as $\mathrm{Mg}$ was found highest in $\mathrm{T} 2$ with $100 \%$ grey water. 


\section{Growth response, yield and fruit quality}

There has been significant effect of treatments on the fresh / dry, root /shoot biomass as well as leaf area of the crop. Compared to other treatments, $\mathrm{T}_{1}(\mathrm{RDF})$, recorded the highest values of these parameters (Table 3). However, in other treatments the differences have been only marginal. The highest yield of brinjal was recorded in $\mathrm{T}_{1}\left(330.04 \mathrm{q} \mathrm{ha}^{-1}\right)$ which might me due to the application of balanced doze of inorganic fertilizers and organic manures to the soil followed by 299.30q ha $\mathrm{ha}^{-1}$ in $5,287.69 \mathrm{q} \mathrm{ha}^{-1}$ in T4, $280.62 \mathrm{q} \mathrm{ha}^{-1}$ in T6, $273.48 \mathrm{q} \mathrm{ha}^{-1}$ in T6 and least $266.30 \mathrm{q} \mathrm{ha}^{-1}$ in T3 (Table 4). Significant increase in growth parameters of crops on application of sewage sludge has also been reported by Bozkurt and Yarilgac, 2003). Quality parameters viz., ascorbic acid and Chl-b were higher in T5 while as TSS, Carbohydrates and proteins were higher in $\mathrm{T} 1$ (Table 5).

Table.1 Physicochemical characteristics of irrigation water

\begin{tabular}{|c|c|c|c|}
\hline \multirow[t]{2}{*}{ Parameters } & \multicolumn{3}{|c|}{ Waste/ Fresh Water } \\
\hline & Black & Grey & Fresh \\
\hline pH $(1: 2.5)$ & 6.80 & 7.42 & 7.10 \\
\hline $\operatorname{EC}\left(\mathrm{dSm}^{-1}\right)$ & 0.85 & 0.78 & 0.47 \\
\hline Alkalinity (mg/l) & 150.2 & 180.99 & 125.13 \\
\hline Nitrate N (mg/l) & 41.09 & 10.0 & 3.36 \\
\hline Phosphate $\left(\mathrm{PO}_{4}\right)(\mathrm{mg} / \mathrm{l})$ & 3.4 & 6.21 & 0.6 \\
\hline Chloride ( $\left.\mathrm{Cl}^{-}\right)(\mathrm{mg} / \mathrm{l})$ & 524.7 & 206.99 & 1.96 \\
\hline Fluoride (F-) (mg/l) & 0.16 & 0.14 & 0.10 \\
\hline Sulphate (mg/l) & 1.785 & 0.804 & 0.529 \\
\hline Ammonium (mg/l) & 169.81 & 90.22 & 2.25 \\
\hline Sodium (mg/l) & 16.53 & 17.78 & 7.31 \\
\hline Potassium (mg/l) & 83.92 & 17.61 & 0.51 \\
\hline Calcium (mg/l) & 47.14 & 48.31 & 23.89 \\
\hline Magnesium (mg/l) & 10.18 & 10.44 & 5.74 \\
\hline Zn $(\mathbf{m g} / \mathbf{l})$ & 0.99 & 5.45 & 0.47 \\
\hline $\mathrm{Cu}(\mathrm{mg} / \mathrm{l})$ & 0.35 & 0.98 & 0.23 \\
\hline $\mathrm{Fe}(\mathrm{mg} / \mathrm{l})$ & 0.57 & 0.88 & 0.10 \\
\hline Mn (mg/l) & 0.17 & 0.65 & 0.08 \\
\hline $\mathrm{Cd}(\mathrm{mg} / \mathrm{l})$ & 0.245 & 0.609 & 0.020 \\
\hline $\mathrm{Cr}(\mathrm{mg} / \mathrm{l})$ & 0.226 & 0.226 & 0.226 \\
\hline $\mathrm{Pb}(\mathrm{mg} / \mathrm{l})$ & 0.001 & 0.001 & 0.001 \\
\hline $\mathrm{Ni}(\mathrm{mg} / \mathrm{l})$ & 0.076 & 0.076 & 0.076 \\
\hline
\end{tabular}


Table.2 Physico- chemical characteristics of the soil of $S$. melongena plots after the treatments

\begin{tabular}{|c|c|c|c|c|c|c|c|c|c|c|c|c|c|c|c|c|}
\hline \multirow{2}{*}{$\begin{array}{l}\text { Treat } \\
\text { ment }\end{array}$} & pH & EC & OC & $\mathbf{N}$ & $\mathbf{P}$ & $\mathbf{K}$ & $\mathrm{Ca}$ & Mg & $\mathbf{C u}$ & $\mathbf{Z n}$ & Mn & $\mathbf{F e}$ & $\mathbf{P b}$ & $\mathbf{N i}$ & Cd & $\mathrm{Cr}$ \\
\hline & & $\mathrm{dSm}^{-1}$ & $(\%)$ & \multicolumn{3}{|c|}{ (kg/ha) } & \multicolumn{10}{|c|}{ (ppm) } \\
\hline $\begin{array}{l}\text { Initial } \\
\text { status }\end{array}$ & 7.56 & 0.26 & 0.75 & 95.74 & 8.42 & 133.8 & 123.75 & 30.58 & 1.18 & 1.41 & 7.92 & 24.14 & 0.98 & 1.92 & 0.012 & 1.76 \\
\hline T1 & 6.95 & 0.20 & 0.99 & 116.8 & 22.2 & 125.25 & 101.66 & 22.05 & 1.05 & 1.61 & 8.83 & 28.9 & 0.99 & 1.98 & 0.011 & 1.72 \\
\hline T2 & 7.53 & 0.52 & 1.05 & 117.25 & 23.08 & 120.81 & 102.11 & 23.05 & 1.69 & 1.21 & 8.95 & 30.14 & 1.01 & 2.2 & 0.014 & 1.98 \\
\hline T3 & 6.24 & 0.63 & 0.98 & 116.99 & 22.88 & 120.09 & 101.12 & 22.95 & 1.73 & 1.91 & 8.94 & 29.95 & 1.05 & 2.36 & 0.014 & 1.97 \\
\hline T4 & 7.51 & 0.91 & 0.91 & 115.89 & 22.9 & 119.05 & 105.81 & 19.9 & 1.19 & 1.18 & 8.81 & 27.91 & 0.99 & 2.38 & 0.170 & 1.85 \\
\hline T5 & 6.55 & 0.51 & 0.91 & 117.2 & 22.5 & 118.95 & 101.99 & 18.85 & 1.25 & 1.11 & 8.92 & 28.91 & 0.99 & 2.21 & 0.017 & 1.8 \\
\hline T6 & 6.60 & 1.05 & 0.95 & 117.35 & 23.25 & 126.01 & 103.85 & 17.51 & 1.45 & 1.01 & 9.05 & 32.23 & 1.04 & 2.19 & 0.016 & 1.95 \\
\hline $\begin{array}{c}\text { C.D } \\
(\mathbf{p} \leq \mathbf{0 . 0 5})\end{array}$ & 0.02 & 0.12 & 0.05 & 10.25 & 2.38 & 15.24 & 11.25 & 2.53 & NS & 0.12 & 0.09 & 5.26 & 0.09 & NS & NS & NS \\
\hline
\end{tabular}

T1: Recommended dose of fertilizers; T2: 100\% Grey water; T3: 100\% Black water; T4: 50\% Grey water+ 50\%RDF; T5: 50\% black water + 50\% RDF; T6: $50 \%$ black water + 50\% Grey water;

Table.3 Effect of different concentrations of wastewater on growth parameters of Solanum melongena L. (Local Long)

\begin{tabular}{|c|c|c|c|c|c|c|c|}
\hline Treatment & $\begin{array}{l}\text { Root } \\
\text { length } \\
\text { (cm) }\end{array}$ & $\begin{array}{l}\text { Shoot } \\
\text { length } \\
\text { (cm) }\end{array}$ & $\begin{array}{l}\text { Root } \\
\text { fresh } \\
\text { Wt (g) }\end{array}$ & $\begin{array}{l}\text { Root dry } \\
\text { Wt (g) }\end{array}$ & $\begin{array}{l}\text { Shoot fresh } \\
\text { Wt (g) }\end{array}$ & $\begin{array}{l}\text { Shoot dry } \\
\text { Wt (g) }\end{array}$ & $\begin{array}{l}\text { Leaf area } \\
\left(\mathrm{Cm}^{2}\right)\end{array}$ \\
\hline T1 & 13.03 & 95.70 & 51.48 & 26.08 & 310.37 & 91.00 & 109.47 \\
\hline $\mathbf{T} 2$ & 12.97 & 79.37 & 43.37 & 23.82 & 260.37 & 69.64 & 88.37 \\
\hline T3 & 12.67 & 82.37 & 31.37 & 17.61 & 177.37 & 49.60 & 83.57 \\
\hline T4 & 12.12 & 87.03 & 54.15 & 26.73 & 268.37 & 80.32 & 71.17 \\
\hline T5 & 13.97 & 83.37 & 34.58 & 22.03 & 237.37 & 54.31 & 90.77 \\
\hline T6 & 14.37 & 90.03 & 26.18 & 17.78 & 157.37 & 37.82 & 94.77 \\
\hline C.D $(p \leq 0.05)$ & 0.79 & 8.21 & 9.79 & 3.19 & 53.55 & 18.61 & 13.41 \\
\hline
\end{tabular}

T1: Recommended dose of fertilizers; T2: 100\% Grey water; T3: 100\% Black water; T4: 50\% Grey water+ 50\%RDF; T5: 50\% black water + 50\% RDF; T6: $50 \%$ black water $+50 \%$ Grey water

Table.4 Effect of different concentrations of wastewater on yield parameters of Solanum melongena L. (Local Long)

\begin{tabular}{|l|l|l|l|l|l|l|l|}
\hline Treatment & $\begin{array}{l}\text { Fruit } \\
\text { No/plant }\end{array}$ & $\begin{array}{l}\text { Fruit } \\
\text { length } \\
\text { (cm) }\end{array}$ & $\begin{array}{l}\text { Fruit } \\
\text { diameter } \\
\text { (cm) }\end{array}$ & $\begin{array}{l}\text { Fruit } \\
\text { weight } \\
\text { (g) }\end{array}$ & $\begin{array}{l}\text { Yield } \\
\text { /plant }\end{array}$ & $\begin{array}{l}\text { Yield/plot } \\
\text { (g) }\end{array}$ & $\begin{array}{l}\text { Yield/ha } \\
\text { (q) }\end{array}$ \\
\hline T1 & 12.03 & 14.67 & 6.70 & 90.79 & 856.50 & 15.18 & $\mathbf{3 3 0 . 0 4}$ \\
\hline T2 & 10.62 & 11.70 & 5.53 & 88.03 & 708.97 & 12.97 & $\mathbf{2 7 3 . 4 8}$ \\
\hline T3 & 10.37 & 13.03 & 5.58 & 88.37 & 690.37 & 12.69 & $\mathbf{2 6 6 . 3 0}$ \\
\hline T4 & 11.12 & 13.70 & 6.03 & 87.37 & 746.12 & 13.58 & $\mathbf{2 8 7 . 6 9}$ \\
\hline T5 & 11.37 & 14.70 & 6.05 & 88.37 & 776.37 & 13.98 & $\mathbf{2 9 9 . 3 0}$ \\
\hline T6 & 10.87 & 14.03 & 5.53 & 87.70 & 727.67 & 13.24 & $\mathbf{2 8 0 . 6 2}$ \\
\hline C.D(p<0.05) & $\mathbf{0 . 7 0}$ & $\mathbf{1 . 0 5}$ & $\mathbf{0 . 4 1}$ & $\mathbf{1 . 2 0}$ & $\mathbf{7 0 . 9 2}$ & $\mathbf{1 . 0 7}$ & $\mathbf{2 8 . 3 1}$ \\
\hline
\end{tabular}

T1: Recommended dose of fertilizers; T2: 100\% Grey water; T3: 100\% Black water; T4: 50\% Grey water+ 50\%RDF; T5: 50\% black water + 50\% RDF; T6: 50\% black water $+50 \%$ Grey water 
Table.5 Effect of different concentrations of wastewater on quality parameters of Solanum melongena L. (Local Long)

\begin{tabular}{|c|l|l|l|l|l|c|c|}
\hline Treatment & $\begin{array}{l}\text { TSS } \\
\text { (Brix) }\end{array}$ & $\begin{array}{l}\text { Ascorbic } \\
\text { acid } \\
\text { (mg/100g) }\end{array}$ & $\begin{array}{l}\text { Chl-a } \\
\text { (mg/g } \\
\text { tissue) }\end{array}$ & $\begin{array}{l}\text { Chl-b } \\
\text { (mg/g } \\
\text { tissue) }\end{array}$ & $\begin{array}{l}\text { Total -chl } \\
(\mathbf{m g} / \mathbf{g} \\
\text { tissue) }\end{array}$ & $\begin{array}{l}\text { Carbohydra } \\
\text { te } \\
(\boldsymbol{\%})\end{array}$ & $\begin{array}{l}\text { Protein } \\
(\mathbf{\%})\end{array}$ \\
\hline T1 & 8.97 & 16.97 & 3.08 & 2.70 & 3.46 & 6.60 & $\mathbf{3 . 7 2}$ \\
\hline T2 & 7.67 & 20.97 & 3.21 & 3.07 & 4.22 & 6.25 & $\mathbf{3 . 6 4}$ \\
\hline T3 & 7.48 & 18.77 & 3.05 & 3.00 & 3.87 & 6.22 & $\mathbf{3 . 6 8}$ \\
\hline T4 & 7.38 & 18.37 & 3.03 & 2.95 & 3.77 & 6.38 & $\mathbf{3 . 7 0}$ \\
\hline T5 & 7.87 & 21.57 & 3.14 & 3.09 & 4.06 & 6.43 & $\mathbf{3 . 7 0}$ \\
\hline T6 & 8.18 & 13.77 & 3.07 & 2.99 & 3.86 & 6.30 & $\mathbf{3 . 6 6}$ \\
\hline C.D(p $\leq \mathbf{0 . 0 5})$ & $\mathbf{1 . 0 8}$ & $\mathbf{3 . 2 4}$ & $\mathbf{0 . 1 0}$ & $\mathbf{0 . 1 7}$ & $\mathbf{0 . 2 9}$ & $\mathbf{0 . 1 6}$ & $\mathbf{0 . 0 4}$ \\
\hline
\end{tabular}

T1: Recommended dose of fertilizers; T2: 100\% Grey water; T3: 100\% Black water; T4: $50 \%$ Grey water+ 50\%RDF; T5: 50\% black water + 50\% RDF; T6: 50\% black water + 50\% Grey water

Table.6 Major nutrient and heavy metals level in fruit of Solanum melongena

\begin{tabular}{|c|c|c|c|c|c|c|c|c|c|c|c|}
\hline \multirow{2}{*}{ Treatments } & \multicolumn{3}{|c|}{ Major Nutrients } & \multicolumn{4}{|c|}{ Micronutrient Cations } & \multicolumn{4}{|c|}{ Heavy metals (ppm) } \\
\hline & $\mathbf{N}$ & $\mathbf{P}$ & $\mathbf{K}$ & $\mathbf{Z n}$ & $\mathrm{Cu}$ & $\mathbf{F e}$ & Mn & $\mathbf{P b}$ & $\mathbf{N i}$ & Cd & $\mathrm{Cr}$ \\
\hline T1 & 1.28 & 0.67 & 1.22 & 10.4 & & 48.5 & & 0.63 & 0.59 & 0.21 & 1.2 \\
\hline $\mathbf{T}$ & 1.10 & 0.44 & 0.86 & 13.61 & 4.9 & 62.9 & & 1.23 & 0. & 0.24 & 1.25 \\
\hline & & & 0.81 & 12 & & 57 & & 1.20 & & & 1.23 \\
\hline $\mathbf{T} 4$ & 1.16 & 0.49 & 1.02 & 11.81 & 4.5 & 54.0 & 24. & 1.04 & 0.58 & 0.18 & 1.12 \\
\hline $\mathbf{T}$ & 1.26 & 0.5 & 1.16 & 11.22 & 4. & & & 1.02 & 0.5 & 0.16 & 1.10 \\
\hline T6 & 1.12 & 0.48 & 0.96 & 12.85 & 4.7 & 60. & 26. & 1.22 & 0.61 & 0.22 & 1.20 \\
\hline C.D $(p \leq 0.05)$ & 0.5 & 0.1 & 0.3 & 0.80 & 0.90 & 2.1 & 1.2 & 0.21 & NS & NS & NS \\
\hline
\end{tabular}

T1: Recommended dose of fertilizers; T2: 100\% Grey water; T3: 100\% Black water; T4: 50\% Grey water+ 50\%RDF; T5: 50\% black water + 50\% RDF; T6: 50\% black water + 50\% Grey water

The major nutrients $(\mathrm{N}, \mathrm{P}, \mathrm{K})$ were found highest in $\mathrm{T} 1$ and the values for $\mathrm{T} 5$ were at par with it. These results reveal that irrigation with black and grey water had a positive effect on plant productivity, probably due to additional nutrient content, thereby a lower cultivation cost is expected due to lesser fertilizer utilization. These findings are in agreement with the findings of Khaled et al., (2013). The accumulation of inorganic elements in fruits (Table 6) was not related to the respective accumulation in soil. Micronutrients ( $\mathrm{Zn}, \mathrm{Cu}, \mathrm{Fe}, \mathrm{Mn}$ ) and Heavy metals exhibited similar trend and highest value was observed for $\mathrm{T} 2$ followed by $\mathrm{T} 6$. The concentration of heavy metals $(\mathrm{Pb}, \mathrm{Ni}$,
$\mathrm{Cd}$ and $\mathrm{Cr}$ ) and microelements was below any toxicity levels. These findings are in conformity with the findings of Arcadia et al., (1998). Thus, regardless of the different concentrations of wastewater treatments alone or in combination or in consonance with recommended fertilizer dose, the concentration of the nutrients varied within the usual levels in plant tissues and did not cause any nutritional problems in the plants (Panoras and Ilias, 1999).

In conclusion, wastewater effectively increased the yield of brinjal crop probably due to high nutrient value of the wastewater. Thus, wastewater can be managed in an 
ecofriendly fashion by its exploitation in the agro-ecosystems. The results show that the accumulation of toxic and nutritive elements in plant tissues and the soil varied in low levels and did not cause any nutritional instability in the plants.

\section{Acknowledgement}

The authors express their gratitude to J\&K State Council for Science and Technology, Department of Science and Technology for providing financial assistance under which this research work was carried out.

\section{References}

AOAC (1984). Official Methods of Analysis of Association of Official Analytical Chemists, Inc. Arlington, Virginia U.S.A.

APHA (2005). Standard Methods for the Examination of Water and Wastewater. $21^{\text {st }}$ Edition, American Public Health Association, Washington, DC.

Arcadia, N. W., Esparza, L. C., Fenn, L. B., Ali, A. S., Miyamoto, S., Figueroa, U. V and Warrick, A. W. (1998). Spatial variability of heavy metals in irrigated alfalfa fields in the upper Rio Grande River basin. Agric. Water Management, 36: 141-156.

Batstone, D. J., Hülsen, T., Mehta, C. M., and Keller, J. (2015). Platforms for energy and nutrient recovery from domestic wastewater: a review. Chemosphere 140, 2-11. doi: 10.1016/j. chemosphere.2014.10.021

Chaw, R., and Reves, A. S. (2001). Effect of waste water on Menthe piperita and Spinacea oleraceae., J. Environ. Biol., 51, 131-145.

Gupta, A. P., Narwal, R. P. and Antil, R. S. (1995). Sewer water composition and its effect on soil properties. Bioresorce
Technology, 65, 171-173

Hesse, P. R. (1971). A Text Book of Soil Chemical Analysis. John Murray Ltd. London, UK. Pp. 528.

Jackson, M. L. (1973). Soil Chemical Analysis, Prentice Hall of India Private Limited, New Delhi, India.

Khaled, S. B., Fathy, S., Nakhlawi, E. L., Saleh, M.I., Samir, G. and AlSolimani. (2013). Treated wastewater use and its effect on water conservation, vegetative yeild, yield components and water use efficiency of some vegetable crops grown under two different irrigation systems in western region, Saudi Arabia. Annual International Interdisciplinary Conference, AIIC Azores, Portugal

Lone, F.A, Qureshi, N., Kirmani, N.A, Sidiquii, S.H., Zaffar, S. and Shah,R.A. 2012 studies on the growth performance, mineral composition and yield of bottle gourd under irrigation with grey water. Nature, Environment and Pollution Technology. 11 (2): 249-252

Nath, Kamlesh, Singh, D., Shyam, S. and Sharma, Y.K. (2009). Phytotoxic effects of chromium and tannery effluent on growth and metabolismof Phaseolus mungo Roxb. J. Environ. Biol., 30, 227-234.

Olsen, S, R., Cole, J. V., Watanabe, F. S. and Dean, L. A. (1954). Estimation of available phosphorus in soils by extraction with sodium bicarbonate. Circular 939. USDA, Washington.

Panoras, G.A. and Ilias, K.A. (1999). Irrigation with reclaimed municipal wastewater. Giachoudi Giapouli Press, Thessaloniki, Greece, $171 \mathrm{p}$

PCB, Pollution Control Board, Andhra Pradesh. (2003). State of the Environment of Andhra Pradesh, www.appcb.org (accessed March 2, 2005). 
Piper,C. S. (1996). Soil and Plant Analysis. Interscience Publ. Inc., New York.

Ramirez-Fuentese, Lucho-Constsntino, C., Escamilla-Silva, E. and Dendooven, L. (2002). Characteristics and carbon and nitrogen dynamics in soil irrigated with waste water for different lengths of time. Bioresource Technol., 85, 179-187

Rattan, R. K.., Datta, S. P., Chhonkar, P. K., Suribabu, K. and Singh, A. K. (2005). Long-term impact of irrigation with waste water effluents on heavy metal content in soils, crops and groundwater- a case study. Agr. Ecosyst. Environ. 109: 310-322.
Shahalam, A., Abu Zahara, M. B. and Jaradat, A. 1998.Wastewater irrigation effect on soil, crop and environment; A pilot scale study at Ibrid, Jordan. Water, Air Soil Pollution, 106: 425-445.

Shao, G., Wang, M., Liu, N., Yuan, M., Kumar, P. and She, D. (2014) Growth and Comprehensive Quality Index of Tomato under Rain Shelters in Response to Different Irrigation and Drainage Treatments. The Scientific World Journal 2014: 1-12 (https://dx. doi.org/10.1155/2014/457937)

Snedecor, G. W. and Cochran, G. W. (1967). Statistical Methods. 6th edition, Iowa Univ. Press, Ames, Iowa.

\section{How to cite this article:}

Farooq A. Lone and Nayar A. Kirmani. 2018. Effect of Wastewater Fertigation on Growth Performance, Yield and Quality Parameters of Solanum melongena L. (Local Long). Int.J.Curr.Microbiol.App.Sci. 7(03): 2138-2145. doi: https://doi.org/10.20546/ijcmas.2018.703.251 